\title{
INVESTIGATING THE SUITABILITY OF PRESSMUD AND COIR PITH FOR USE AS SOILLESS SUBSTRATE BY SEM, XRF, UV-VIS AND FTIR SPECTROSCOPY TECHNIQUES
}

\author{
PRAGYAN PARAMITA ROUT and K. ARULMOZHISELVAN \\ Department of Soil Science and Agricultural Chemistry, Tamil Nadu Agricultural University, Coimbatore \\ 641003, India \\ Corresponding author: Pragyan Paramita Rout, parimita.pragyan00@gmail.com
}

Received August 15, 2018

\begin{abstract}
Pressmud and coir pith are bulk organic substrates useful for constituting soilless media. In the instrumental investigation, the lignocellulosic organic substances predominant in coir pith and pressmud were characterized in terms of proximate constituents, elemental composition and functional groups. The elemental composition studies by X-ray fluorescence spectroscopy (XRF) and proximate constituent analysis showed that both coir pith and pressmud contain sufficient amounts of macro- and micro-nutrients, as well as important organic constituents, such as sugar, cellulose, protein and wax. Scanning electron micrographs (SEM) revealed the fibrous and porous nature of both substrates. UVvisible and Fourier transform infrared spectroscopic analyses revealed the presence of lignin, hemicellulose and cellulose, and other characteristics of natural fibers. The cation and anion exchange reactions and the adsorption phenomenon exhibited by coir pith and pressmud were attributed to the functional groups on their surfaces. Hence, the findings support their suitability as a growing substrate for soilless crop production.
\end{abstract}

Keywords: coir pith, FTIR spectroscopy, XRF, SEM, lignocellulosic waste, pressmud, soilless substrate

\section{INTRODUCTION}

Soilless crop production techniques within protected agriculture systems have been identified as a pivotal innovation to sustain profitable agriculture globally over the last few decades. ${ }^{1}$ Soilless culture includes the methods of growing plants in a rooting medium without the use of soil material. These methods generally involve containerization of plant roots within a porous material known as 'substrate' or 'growbag medium'. ${ }^{2}$ Growbag cultivation is one of the simplest and most user-friendly soilless cultivation techniques, ${ }^{3}$ which could be adopted to achieve prompter harvest from a small piece of land, alleviating the environmental risks associated with soil-based cultivation systems. ${ }^{4-7}$

The selection of an appropriate substrate composition based on technical and economic feasibility is a vital aspect of research and key to success in any soilless production system. ${ }^{8}$ The composition of growbag media may be either inorganic (e.g. perlite, rockwool, vermiculite etc.) or organic in nature. ${ }^{9}$ Currently, organic materials have become the focus of most intensive research attributed to their widespread availability, low cost, easy disposal, renewable and eco-friendly nature. $^{10-11}$

Pressmud is a compressed sugar industry byproduct, a fibrous residue remaining after the crushing and extraction processes of juice from sugarcane stalks. Pressmud is also useful for agricultural and horticultural crops due to its richness in plant nutrients. It has been well evidenced that it contains about $1.9 \% \mathrm{~N}, 1.8 \% \mathrm{P}$, $0.9 \% \mathrm{~K}, 4.3 \% \mathrm{Ca}, 0.7 \% \mathrm{Mg}, 3.2 \% \mathrm{~S}, 0.034 \% \mathrm{Mn}$, $0.008 \% \mathrm{Zn}$ and $0.053 \% \mathrm{Cu}^{12}$ The typical composition of pressmud comprises about 26.6$54.3 \%$ cellulose, $22.3-29.7 \%$ hemicellulose and $14.3-24.4 \%$ lignin. ${ }^{13}$ In sugar mills in India, about 12 million tons of pressmud is produced as a waste from double sulphitation and carbonation processes,${ }^{14}$ whereas about 54 million dry tons of pressmud is produced annually throughout the world. ${ }^{15}$ Usually, dry pressmud is disposed of in the open field or sold as immature compost to farmers. Pressmud also has the potential of energy generation through biological and thermal processing, such as biomethanation, pyrolysis and gasification. ${ }^{16}$ 
Dry pressmud can be exploited as a potential source of biogas, as it contains higher percentage of combustibles. Pressmud also has wide application in agriculture either as compost or as biofertilizer. ${ }^{17}$ Besides, it is used as promising substrate/medium for soilless crop production. It was suggested that the incorporation of rice hulls and pressmud in soilless substrates improved the growth, quality and flower yield of rose. ${ }^{18}$

Coir pith is an indigenously available agricultural organic solid byproduct, generated during the process of extraction of fibers from coconut husk. Raw coir pith consists of $35 \%$ cellulose, $25.2 \%$ lignin, $7.5 \%$ pentosanes, $1.8 \%$ fat and resins, $8.7 \%$ ash, $11.9 \%$ moisture and $10.6 \%$ of other nutrients. ${ }^{19}$ Coir pith also acts as an adsorbent for removing pollutants from waste water. ${ }^{20}$ Because of its low degradation rate in the environment, as a consequence of its high lignin content and $\mathrm{C} / \mathrm{N}$ ratio, ${ }^{21}$ raw coir pith accumulates as hillocks on lands, causing serious health hazards. During 2012, there was an accumulated stock of 10 million tons of coir pith in southern states, ${ }^{22}$ while overall in India, about 0.75 million tons of coir pith are produced annually. ${ }^{23}$ For every ton of fiber extracted, the pith is produced to the extent of 2 tons. ${ }^{24}$ Although composting is an alternative method of treating raw coir pith and converting it into a readily usable form, the efficiency of composting still suffers drawbacks as it takes several months to obtain mature coir pith compost. $^{25}$

Many researchers have investigated the use of agro-industrial byproducts, viz., tree bark, sawdust, sewage sludge, municipal solid waste, as soilless substrates. ${ }^{26-27} \mathrm{~A}$ study on coir pith, sewage sludge and compost incorporated equally in garden soil, silt and leaf mould indicated that the incorporation of coir pith and compost lowered the $\mathrm{pH}$, maintained the optimum EC and increased the organic carbon content, which helped to improve the nutrient uptake, yield and quality of marigold. ${ }^{28}$ In another study, it was found that a medium consisting of leaf compost exhibited better performance, compared to peat, farm yard manure and silt, for growing potted rose. ${ }^{29}$ The performance of a soilless substrate containing biochar from conifer wood in combination with peat, i.e. $40 \%$ peat $/ 60 \%$ biochar, was evaluated for growing ornamental crops and it was found that biochar addition to peat increased $\mathrm{pH}, \mathrm{EC}$ and $\mathrm{K}$ content, as well as porosity and bulk density. ${ }^{30}$
The agronomic value of any organic soilless substrate, its beneficial effect on growth, yield and quality of crops, as well as its residual effect on the environment, is closely linked to the nature and dynamics of its constituent organic fractions. ${ }^{31}$ Besides, the organic fractions also improve the moisture retention, nutritional support and biological properties of the substrate, which promote plant growth. ${ }^{32}$ Therefore, a deeper investigation of the organic fractions of these substrates could provide information on the quality (stability and maturity) of growbag media. ${ }^{33}$ Fourier transform infrared (FTIR) spectroscopy is a modern non-destructive method often used for characterization of functional groups in organic substrates, and can thereby elucidate their ion exchange and adsorption behavior. ${ }^{34} \mathrm{~A}$ compost based growing medium was characterized using thermal and spectroscopic techniques and its suitability as soilless substrate was found. ${ }^{35}$ Other techniques, viz., scanning electron microscopy (SEM) and Xray fluorescence (XRF) spectroscopy analysis, also give information on the surface properties and elemental composition of growing substrates.

Keeping in view the wide applicability of soilless cultivation, the present study was undertaken to analyze the proximate constituents, elemental composition and characterization of functional groups in pressmud, coir pith using modern instruments and analytical methodologies. The study aimed to explore the potential of pressmud and coir pith for use as substrates for soilless cultivation.

\section{EXPERIMENTAL}

Sample collection and preparation

Crude pressmud was collected from Banari Amman Sugars Private Limited, Sathyamangalam, Erode, and raw coir pith was obtained from a commercial nursery unit, Coimbatore, Tamil Nadu. The pressmud was sun dried and dirt was removed. Similarly, coir pith blocks were soaked in water to loosen the pith fibers, then sun dried and finally stored for analysis.

\section{Analytical methodology}

The analytical techniques used to characterize the proximate constituents, elemental composition, functional groups and organic compound profile of pressmud and coir pith are detailed below.

\section{Proximate composition analysis}

The coir pith and pressmud were analyzed to determine the proximate composition of the samples collected in triplicates. Moisture, ash, dry matter, 
nitrogen, crude protein, sugar and crude wax contents were estimated as per standard methods. ${ }^{36-37}$

\section{Analysis of elemental composition by $\mathrm{XRF}$}

The elemental composition of pressmud and coir pith was determined by using an X Supreme $8000 \mathrm{XRF}$ spectrometer (Oxford Instruments), configured for Energy Dispersive X-ray fluorescence (EDXRF) with sequential measurement, which complies with ASTM D4294, ISO8754, ISO20847 and ISO13032 test methods. This spectrometer is equipped with an X-ray tube having $\mathrm{W}, \mathrm{Pd}$ or $\mathrm{Ti}$ targets and a maximum of 5 filters. It has 10 sample holding tubes with an analysis diameter of $47 \mathrm{~mm}$. Helium gas was used in the helium purge unit as quench gas, with a mean flow rate of 3 $\mathrm{L} / \mathrm{min}$. The detector used was high resolution silicon drift (SDD). The detection limit ranges from ppm to $\%$. Finely ground, $0.5 \mathrm{~mm}$ mesh powdered samples of pressmud and coir pith were fed into the instrument for analysis.

\section{SEM analysis}

The scanning electron microscopy (SEM) analysis of pressmud and coir pith was carried out using a FEIQuanta 250 model SEM, with an acceleration voltage of $30 \mathrm{kV}$, to study the surface features and morphology. The sample was fed in the form of fine powder $(0.5 \mathrm{~mm}$ mesh). It was sputtered with a thin layer of gold prior to SEM analysis. The instrument is equipped with field emission gun (FEG) systems that take surface images with a resolution of $1.4 \mathrm{~nm}$.

\section{$U V$-visible spectrometric analysis}

A known quantity (10 g) of both pressmud and coir pith was extracted using hexane as solvent $(250 \mathrm{~mL})$ for spectroscopic measurement. The solvent was scanned across the wavelength range from 200 to 700 $\mathrm{nm}$, with a maximum scanning speed of $400 \mathrm{~nm} / \mathrm{s}$ and resolution of $1.5 \mathrm{~nm}$, by using a Varian Cary $50 \mathrm{UV}$ VIS spectrophotometer.

\section{FTIR spectroscopic analysis}

A JASCO FTIR-6800 model FTIR spectrometer, with pyroelectric TGS (triglycine sulfate) detector, was employed to determine the presence of functional groups in pressmud and coir pith. The solid film technique was used for sample preparation. The FTIR spectrometer scanned over the frequency range of $4000-350 \mathrm{~cm}^{-1}$ at a resolution of $4 \mathrm{~cm}^{-1}$. The spectrum was collected using Spectra Manager TM CrossPlatform Software.

\section{Statistical analysis}

The analytical data recorded for the characterization of proximate composition and elemental composition of pressmud and coir pith were subjected to statistical analysis using SPSS 13.0 version software for Windows. The analysis was carried out in triplicates and the results were expressed as means of three replications \pm standard deviation (SD). The significant differences $(\mathrm{P}<0.01)$ of the mean values calculated for each element in different analyses were compared by one-way ANOVA.

\section{RESULTS AND DISCUSSION Proximate composition}

The data on proximate constituents (Table 1) showed that pressmud contained moisture $(62.39 \%)$, sugar $(12.67 \%)$, crude wax $(8.11 \%)$, crude protein $(10.38 \%)$ and nitrogen $(1.66 \%)$. Similar proximate constituents in pressmud have been also reported earlier. ${ }^{38-39}$ Similarly, coir pith was found to have high content of crude fibre $(52.53 \%)$, consisting of hemicellulose $(9.70 \%)$, cellulose (11.52\%) and lignin (31.31\%), hence coir pith remains a recalcitrant agro-residue, resisting decomposition by microorganisms under natural conditions. ${ }^{40}$ The presence of such natural fibers in Argan press cake, an agricultural waste, was also confirmed in previous studies. ${ }^{41}$

The C:N ratio is an indicator of $\mathrm{OM}$ origin, stability and maturity. There was a great variability in the $\mathrm{C}: \mathrm{N}$ ratio between the media. The pressmud recorded a $\mathrm{C}: \mathrm{N}$ ratio of 31:1. However, the coir pith recorded a higher C:N ratio (105:1). This might be due to the presence of carbon-rich long-chain polymeric organic compounds, characteristics of natural fibre. ${ }^{24}$ The high $\mathrm{C}: \mathrm{N}$ ratio in such substrate could cause temporary immobilization of soluble nitrogen, when used as growing medium. This $\mathrm{N}$ deficit can be overcome when using coir by applying $\mathrm{N}$ fertilizers. ${ }^{42}$

\section{Mineral elemental composition}

The mineral elemental composition of both pressmud and coir pith (Table 2) was studied by the XRF technique. It was recorded that pressmud contained $1.66 \% \mathrm{~N}, 4.17 \% \mathrm{P}_{2} \mathrm{O}_{5}, 1.13 \% \mathrm{~K}_{2} \mathrm{O}$ and $3.04 \% \mathrm{SO}_{2}$.

However, coir pith had macronutrients, viz., $0.51 \% \quad \mathrm{~N}, \quad 0.07 \% \quad \mathrm{P}_{2} \mathrm{O}_{5}$ and $0.86 \% \quad \mathrm{~K}_{2} \mathrm{O}$. In comparison with coir pith $\left(0.84 \% \mathrm{SO}_{2}, 0.41 \%\right.$ $\mathrm{CaO}$ ), the pressmud was found to be a rich source of sulphur and calcium $\left(3.04 \% \mathrm{SO}_{2}, 4.38 \% \mathrm{CaO}\right)$. Besides, pressmud and coir pith were found to also contain measurable micronutrients $(\mathrm{Fe}, \mathrm{Cu}$, $\mathrm{Mn}$ and $\mathrm{Zn}$ ). Silicon was present in nondetectable quantity in both pressmud and coir pith. Other elements, such as $\mathrm{Ti}, \mathrm{Sr}, \mathrm{Zr}, \mathrm{Ba}$ and $\mathrm{Rb}$, were found in traces. Moreover, toxic heavy metals, such as $\mathrm{Hg}, \mathrm{Pb}, \mathrm{As}$ and $\mathrm{Cd}$, were absent from both samples. ${ }^{43}$ 


\section{PRAGYAN PARAMITA ROUT and K. ARULMOZHISELVAN}

Table 1

Proximate composition (\%) of pressmud and coir pith

\begin{tabular}{lcc}
\hline Parameter & Pressmud & Coir pith \\
\hline Moisture & $62.39 \pm 0.01$ & $5.59 \pm 0.56$ \\
Dry matter & $37.61 \pm 0.14$ & $94.41 \pm 0.27$ \\
Ash content & $10.27 \pm 0.16$ & $7.92 \pm 0.11$ \\
Organic matter & $89.73 \pm 0.23$ & $92.08 \pm 0.34$ \\
Crude wax & $8.11 \pm 0.02$ & - \\
Crude protein & $10.38 \pm 0.05$ & $3.19 \pm 0.07$ \\
Crude fibre & $32.6 \pm 0.09$ & $52.53 \pm 0.15$ \\
Sugar & $12.67 \pm 0.27$ & - \\
Cellulose & $12.4 \pm 0.01$ & $11.52 \pm 0.08$ \\
Hemicellulose & $10.7 \pm 0.07$ & $9.70 \pm 0.19$ \\
Lignin & $9.5 \pm 0.03$ & $31.31 \pm 0.10$ \\
Total nitrogen $(\%)$ & 1.66 & 0.51 \\
C:N ratio & $31: 1$ & $105: 1$ \\
\hline
\end{tabular}

Values are expressed as mean \pm SD of three replications for each parameter

Table 2

Elemental composition (\%) of pressmud and coir pith determined by XRF on dry weight basis

\begin{tabular}{ccc}
\hline Elemental composition & Pressmud & Coir pith \\
\hline $\mathrm{Na}_{2} \mathrm{O}$ & 0.11 & 0.09 \\
$\mathrm{MgO} \mathrm{Al}_{3}$ & 1.23 & 1.89 \\
$\mathrm{SiO}_{2}$ & 0.65 & 0.27 \\
$\mathrm{P}_{2} \mathrm{O}_{5}$ & $\mathrm{ND}$ & $\mathrm{ND}$ \\
$\mathrm{SO}_{2}$ & 4.17 & 0.07 \\
$\mathrm{~K}_{2} \mathrm{O}$ & 3.04 & 0.84 \\
$\mathrm{CaO}$ & 1.13 & 0.86 \\
$\mathrm{Cl}$ & 4.38 & 0.41 \\
$\mathrm{Ti}, \mathrm{Sr}, \mathrm{Zr}, \mathrm{Ba}$ and $\mathrm{Rb}$ & 0.007 & 0.11 \\
$\mathrm{Micronutrients}(\mathrm{ppm})$ & $\mathrm{Tr}$ & $\mathrm{Tr}$ \\
\hline $\mathrm{Fe} \mathrm{O}_{3}$ & & \\
$\mathrm{CuO}$ & 170.35 & 3.79 \\
$\mathrm{MnO}_{2}$ & 4.31 & 5.39 \\
$\mathrm{ZnO}$ & 30.38 & 29.42 \\
\hline
\end{tabular}

Minimum detection limit is $1 \mathrm{ppm}$ for all tested elements; Tr stands for trace amount and ND for not detectable; Values are expressed as mean \pm SD of three replications for each parameter

\section{Scanning electron microscopic studies}

SEM is widely used to study the morphological features and surface characteristics of adsorbent materials. ${ }^{44-45}$ The resulting SEM micrographs of pressmud and coir pith shown in Figure $1(\mathrm{a}, \mathrm{b})$ provide a qualitative confirmation of morphology, surface texture and porosity. In the pressmud sample, the aggregates of biomass were arranged into cellulose fibers and the protein matrix was strongly bound. ${ }^{46-47}$ The SEM image of pressmud extracted from sugar beet and sugarcane presents a fibrous structure with surface porosity of 20-25 $\mu \mathrm{m}^{48}$

The SEM micrograph of coir pith indicates the existence of an open mouth matrix and thickly packed thin-walled ribbon-shaped cells with intermediate pores between the pith tissues. The matrix looked like a tubular honey comb with a large number of void space or pores ${ }^{49}$ and was indicative of a robust and relatively contiguous structure, apparently bound to lignin containing fibers. ${ }^{50}$ Such surface morphology might be due to the fibrous nature of the raw material, as it is extracted from coconut shell through the retting process. ${ }^{51}$ Similar thin-walled cells and pores in coir pith were also observed during the evaluation of radium adsorption from aqueous solution. ${ }^{52}$

\section{UV-visible spectroscopic studies}

UV-visible spectra of pressmud and coir pith (Fig. 2) were studied over a wavelength range of 
200-700 nm with due sharpness of the peak and a proper baseline. The spectrum of pressmud (Table 3) showed peaks at 229 and $276 \mathrm{~nm}$, in the UV range of 200-400 nm, with absorbance of 2.630 and 1.253 respectively. This could be attributed to the fact that fatty acids, conjugated dienes and hydro peroxides formed as a result of lipid oxidation in pressmud wax, absorbed UV light at about $230 \mathrm{~nm}$ and conjugated trienes at about 270 $\mathrm{nm} .^{53}$ Also, in the visible range $(500-600 \mathrm{~nm})$, no peaks were found, indicating the absence of carotenoids. ${ }^{54}$ The wax extracted from Linum usitatissimum, ${ }^{55}$ sugarcane peel and straw, ${ }^{56}$ has shown similar UV-vis patterns.
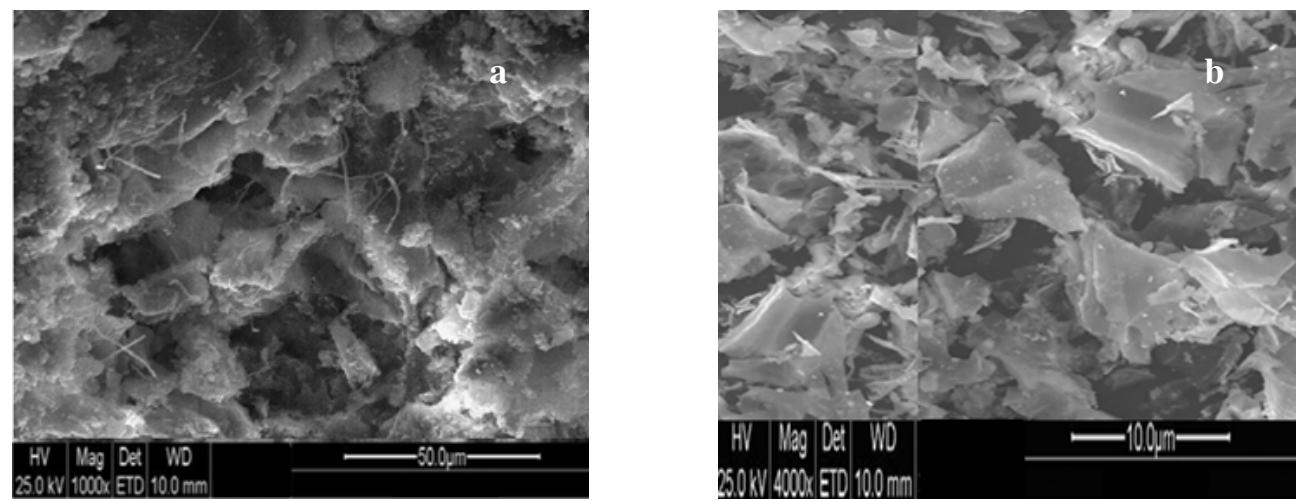

Figure 1: Scanning electron micrographs of pressmud (a) and coir pith (b)
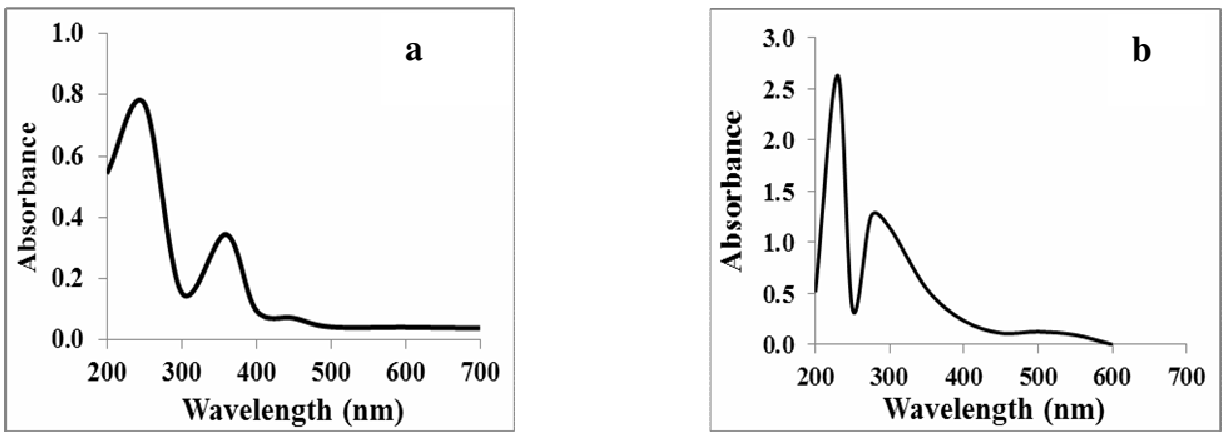

Figure 2: UV-visible spectra of pressmud (a) and coir pith (b) extracted with hexane

Table 3

UV-visible spectral peak values of pressmud and coir pith extracted with hexane

\begin{tabular}{|c|c|c|c|}
\hline Sample & Wavelength (nm) & Absorbance & Detectable compounds \\
\hline \multirow[t]{2}{*}{ Pressmud } & 229 & 2.630 & $\begin{array}{l}\text { Fatty acids, conjugated dienes and hydro } \\
\text { peroxides }\end{array}$ \\
\hline & 276 & 1.253 & Conjugated trienes \\
\hline \multirow[b]{2}{*}{ Coir pith } & 254 & 0.772 & Guaiacyl and syringyl ortho and para quinones \\
\hline & 365 & 0.345 & $\begin{array}{l}\text { Carbonyl groups and/or double bonds } \\
\text { conjugated with aromatic ring of lignin }\end{array}$ \\
\hline
\end{tabular}

Similarly, the UV-visible spectrum of coir pith (Table 3) recorded two characteristic peaks at 254 $\mathrm{nm}$ and $365 \mathrm{~nm}$, with absorbance of 0.772 and 0.345 , which might be indicative of the presence of complex polyphenols and quinones in the lignin backbone. ${ }^{57-58}$ The free and etherified hydroxyl groups of guaiacyl and syringyl orthoand para-quinones contribute to the characteristic absorption maximum of lignin near $250 \mathrm{~nm} .^{59}$ The absorption peak at 300 to $400 \mathrm{~nm}$ is due to carbonyl groups and/or double bonds conjugated with an aromatic ring of lignin. ${ }^{60}$ This might be attributed due to the fact that lignin absorbs more strongly in the UV and visible regions than polysaccharides, such as cellulose and hemicellulose. ${ }^{61}$

\section{FTIR spectroscopy studies}

The FTIR technique is an important tool to identify the characteristic functional groups in 
compounds. The chemical structure of adsorbents is also of vital importance in understanding the adsorption process. Hence, this technique was used for structural characterization of pressmud and coir pith.

\section{FTIR analysis of pressmud}

The FTIR analysis of pressmud (Fig. 3) revealed the presence of many organic functional groups, indicating their respective compounds by comparison of the absorption frequencies of various organic functional groups. ${ }^{53}$ It showed a broad band between 3000 and $3800 \mathrm{~cm}^{-1}$, with little peaks around 3267.79 and $2916.81 \mathrm{~cm}^{-1}$. This indicated the presence of both free and hydrogen bonded $\mathrm{OH}$ groups in the alcohols from the cellulose structure ${ }^{62}$ or due to the stretching of the silanol group $(\mathrm{Si}-\mathrm{OH})$ on the adsorbent surface. ${ }^{63}$ The peak at $2916.21 \mathrm{~cm}^{-1}$ could be due to the symmetric and asymmetric $\mathrm{H}-\mathrm{C}-\mathrm{H}$ stretching in alkanes. A similar peak at 2921.73 and $2851.64 \mathrm{~cm}^{-1}$ was also observed in sugarcane peel wax. ${ }^{56}$

The transmittance in the $1027.87 \mathrm{~cm}^{-1}$ region could be attributed to -OCO- and -C-O stretch in alcohols, esters and ethers, which would also indicate the presence of lactones and polysaccharides. ${ }^{64}$ Such peaks were comparable with the band at $1078.66 \mathrm{~cm}^{-1}$ in pressmud. ${ }^{46}$ The IR spectra indicated a weak and broad peak at $1593.88 \mathrm{~cm}^{-1}$, corresponding to $\mathrm{C}=\mathrm{C}$ bending in aromatic ring and alkenes. ${ }^{65}$ The presence of such polar groups on the surface is likely to impart considerable cation exchange capacity to the adsorbents. ${ }^{66}$ The peak at $550.58 \mathrm{~cm}^{-1}$ indicated the presence of the $\mathrm{Si}-\mathrm{H}$ group.

\section{FTIR analysis of coir pith}

The absorption spectrum of the infrared region in coir pith (Fig. 4) is mainly attributed to the presence of lignin, hemicellulose and cellulose, characteristic of natural fibers. In general, the IR spectra for native and chemically modified fibers are represented in the $3200-3600 \mathrm{~cm}^{-1}$ range. ${ }^{67}$ This formation of a broad, round band could be attributed to axial deformation of the hydroxyl $(\mathrm{O}-\mathrm{H})$ group depicting the presence of alcohols. For the coir pith used in the study, such a peak appeared at $3326.61 \mathrm{~cm}^{-1}$. At $2083.71 \mathrm{~cm}^{-1}$, the observed absorption band might be due to very week stretching of $\mathrm{C} \equiv \mathrm{C}$ bonds in alkynes present internally in the structural $\mathrm{C}$ framework.

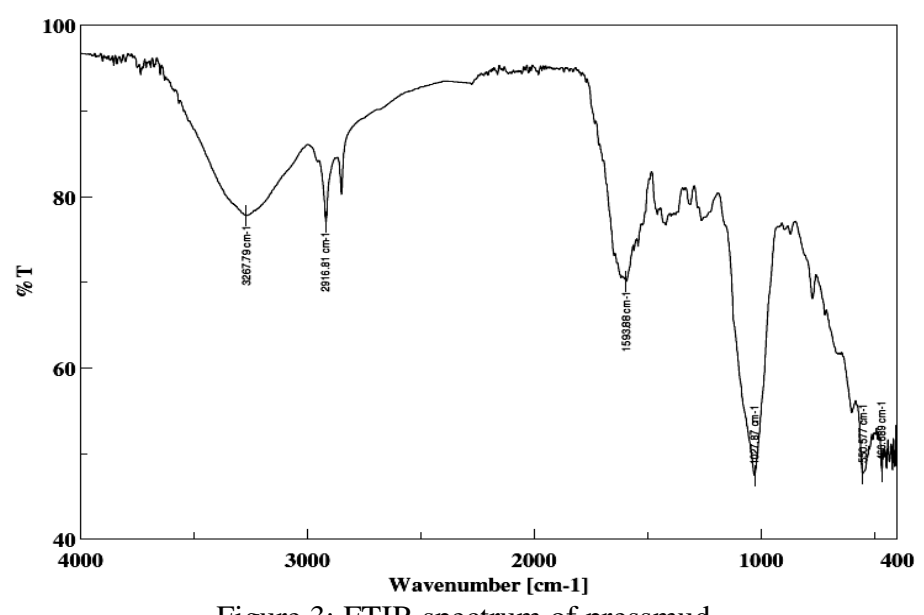

Figure 3: FTIR spectrum of pressmud 


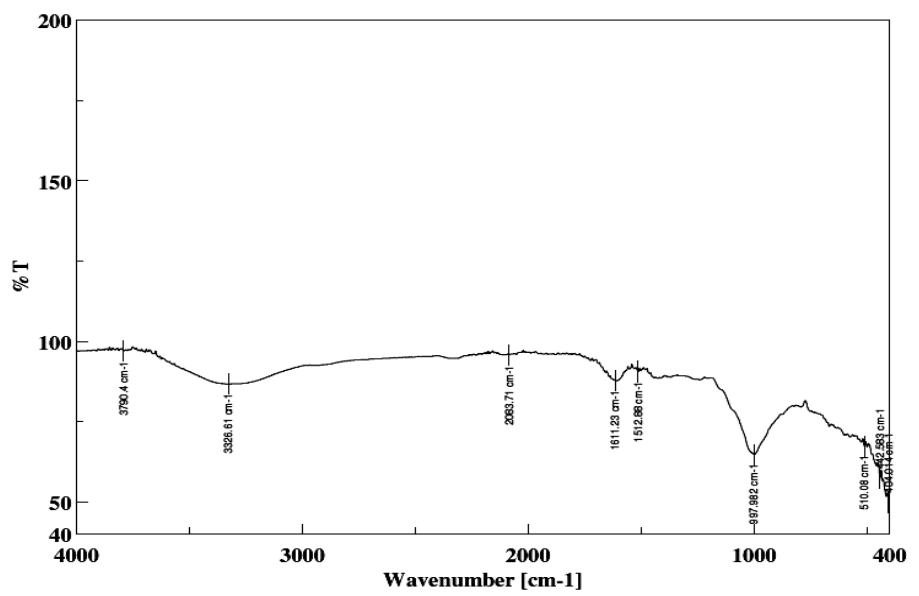

Figure 4: FTIR spectrum of coir pith

The peak at $1611.23 \mathrm{~cm}^{-1}$ might be associated with the presence of the carbonyl group $(\mathrm{C}=\mathrm{O})$ of hemicellulose in coir pith. ${ }^{68}$ The band at 3790.40 $\mathrm{cm}^{-1}$ could have been formed due to weak stretching of $\mathrm{N}-\mathrm{H}$ groups, and might be an indication of the presence of primary amines and amides. At $1512.88 \mathrm{~cm}^{-1}$, the band could be related to axial starch of aromatic $\mathrm{C}=\mathrm{C}$ groups that typically signify the presence of lignin, a prominent constituent of coir pith. ${ }^{69}$ The presence of lignin, in turn, imparts resistance against degradation, due to the complex carbon backbone and high degree of polymerization. The strong absorption band at $997.98 \mathrm{~cm}^{-1}$ is indicative of the $\mathrm{C}-\mathrm{O}$ bond stretch in alcohols and esters. The stretched adsorption peak at $510.08 \mathrm{~cm}^{-1}$ could be assigned to the presence of alkyl halide and disulphide groups. ${ }^{70}$

\section{CONCLUSION}

The elemental composition studies by the XRF method and proximate composition analysis revealed that both pressmud and coir pith contain sufficient amounts of macro- and micro-elements, as well as other important organic constituents, including sugar, cellulose, protein and wax, and thus could serve as a substantial source of primary nutrients for crop growth. The analysis of FESEM micrographs revealed the fibrous and porous nature of both pressmud and coir pith, their high surface area and porosity, which would impart proper aeration for roots in a growing substrate. Spectroscopic techniques, such as UV-Visible spectroscopy and FTIR analysis, confirmed the presence of lignin, hemicellulose and cellulose, which are the main characteristics of natural fibers, capable of absorbing a large volume of water. FTIR analysis also showed that the studies materials exhibited cation exchange reactions and the adsorption phenomenon, due to the presence of functional groups on their surfaces. This, in turn, provides a conductive physical, chemical and biological environment for crop growth. Therefore, these renewable and environmentally sustainable lignocellulosic organic materials, viz., pressmud and coir pith, could be recognized as ideal soilless substrates for protected cultivation. Further, such use of these organic materials paves the way for recycling wastes and byproducts, contributing to alleviating environmental pollution, minimizing the risks associated with soil-based cultivation, while also improving crop productivity.

\section{REFERENCES}

1 G. Schmilewski, Acta Hortic., 819, 33 (2009), https://doi.org/10.17660/ActaHortic.2009.819.3

2 D. Savvas, G. Gianquinto, Y. Tuzel and N. Gruda, FAO Plant Production and Protection Paper 217, 2013, pp. 355-378, http://www.fao.org/home/en/

A. R. Nejad and A. Ismaili, J. Sci. Food Agric., 94, 905 (2014), https://doi.org/10.1002/jsfa.6334

4 M. Albaho, B. Thomas, S. Isathali, P. George and D. Ghloum, Acta Hortic., 1037, 1087 (2014), https://doi.org/10.17660/ActaHortic.2014.1037.144

5 M. Raviv and J. H. Lieth, "Soilless Culture: Theory and Practice", Academic Press, San Diego, USA, 2008, https://www.elsevier.com/books/soilless-culturetheory-and-practice/raviv/978-0-444-52975-6

6 D. Savvas and N. Gruda, Eur. J. Hortic. Sci., 83, 280 (2018), https://doi.org/10.17660/eJHS.2018/83.5.2

7 D. Savvas, G. B. Oztekin, M. Tepecik, A. Ropokis, Y. Tüzel et al., J. Hortic. Sci. Biotechnol., 92, 294 (2017), https://doi.org/10.1080/14620316.2016.1265903

8 S. F. Vaughn, N. A. Deppe, D. E. Palmquist and M. A. Berhow, Ind. Crop. Prod., 33, 51 (2011), https://doi.org/10.1016/j.indcrop.2010.10.034 
9 A. P. Papadopoulos, A. Bar-Tal, A. Silber, U. K. Saha and M. Raviv, in "Soilless Culture: Theory and Practice", edited by M. Raviv and J. H. Lieth, Academic Press, San Diego, USA, 2008, p. 505, https://www.elsevier.com/books/soilless-culturetheory-and-practice/raviv/978-0-444-52975-6

10 M. Raviv, Acta Hortic., 982, 39 (2013), https://doi.org/10.17660/ActaHortic.2013.982.3

11 N. Gruda, D. Savvas, G. Colla and Y. Rouphael, Eur. J. Hortic. Sci., 83, $319 \quad$ (2018), https://doi.org/10.17660/eJHS.2018/83.5.5

12 N. Partha and M. R. V. Krishnan, Kisan World, 27, 35 (2000), www.kisanworldpk.com/

13 S. Katyal, K. Thambimuthu and M. Valix, Renew. Energ., 28, 713 (2003), https://doi.org/10.1016/S09601481(02)00112-X

14 N. Partha and V. Sivasubramanian, Ind. Chem. Eng., $\quad 48, \quad 160 \quad$ (2006), https://www.researchgate.net/publication/264547627

15 D. R. Mulinari, H. J. C. Voorwald, M. O. H. Cioffi and C. P. Silva, Carbohyd. Polym., 75, 317 (2009), https://doi.org/10.1016/j.carbpol.2008.07.028

16 N. Joshi and S. Sharma, Report and Opinion, 2, 79 (2010), https://doi.org/10.11648/j.ijfsb.20160101.14

17 K. Chand, N. C. Shahi, U. C. Lohani and S. K. Garg, Sugar Tech., 13, 81 (2011), https://doi.org/10.1007/s12355-010-0059-8

18 K. Rasappan, A. Kumar and P. Santhosh, Int. J. Chem. Sci., 13, $1333 \quad$ (2015), https://www.researchgate.net/publication/284747168

19 S. Tripetchkul, K. Pundee, S. Koonsrisuk and S. Akeprathumchai, Int. J. Recycl. Org. Waste Agric., 15, 1 (2012), https://doi.org/10.1186/2251-7715-1-15

20 I. Ali, M. Asim and T. A. Khan, J. Environ. Manage., $\quad \mathbf{1 1 3}, \quad 170 \quad$ (2012), https://doi.org/10.1016/j.jenvman.2012.08.028

21 A. Bhatnagar and M. Sillanpaa, Chem. Eng. J., 157, 277 (2010), https://doi.org/10.1016/j.cej.2010.01.007

22 A. Reghuvaran and A. D. Ravindranath, Int. J. Biol. Pharm. Allied Sci., 3, 88 (2014), http://www.ijbpas.com/

23 Coir Board, International Coir Fair-2016, Coir Board, Kerala, Ministry of MSME, Government of India, 2016

24 M. A. Chowdhury and K. J. Fatema, Int. J. Text. $\begin{array}{llll}\text { Sci., } & \mathbf{5}, & 132 & \end{array}$ https://doi.org/10.5923/j.textile.20160506.02

25 S. Rangabhashiyam, N. Anu and N. Selvaraju, J. Environ. Chem. Eng., 1, 629 (2013), https://doi.org/10.1016/j.jece.2013.07.014

${ }^{26}$ F. Guerrero, J. M. Gasco and L. HernandezApaolaza, J. Plant Nutr., 25, 129 (2002), https://doi.org/10.1081/PLN-100108785

27 M. Benito, A. Masaguer, R. De Antonio and A. Moliner, Bioresour. Technol., 96, 597 (2005), https://doi.org/10.1016/j.biortech.2004.06.006

${ }^{28}$ I. Ahmad, A. Ahmad, S. Ahmad, A. Amjad, M. Saleem et al., Int. J. Agric. Biol., 14, 116 (2012), http://www.fspublishers.org/index.php
29 A. Younis, A. Riaz, F. Javaid, M. Ahsan, U. Tariq et al., Curr. Sci. Perspect., 1, 16 (2015), http://bosaljournals.com/csp/

30 V. Dispenza, C. De Pasquale, G. Fascella, M. M. Mammano and G. Alonzo, Span. J. Agric. Res., 14, 1 (2016), https://doi.org/10.5424/sjar/2016144-9082

31 J. Peuravuori, A. Monterio, L. Eglite and K. Pihlaja, Talanta, 65, $408 \quad$ (2005), https://doi.org/10.1016/j.talanta.2004.06.042

32 J. Chen, B. Gu, E. J. Le Boeuf, H. Pan and S. Dai, Chemosphere, $\quad 48, \quad 59 \quad$ (2002), https://doi.org/10.1016/S0045-6535(02)00041-3

${ }_{33}$ W. H. McDowell, A. Zsolnay, J. A. AitkenheadPeterson, E. G. Gregorich, D. L. Jones et al., Soil Biol. Biochem., 38, 1933 (2006), https://doi.org/10.1016/j.soilbio.2005.12.018

34 E. Smidt, K. Meissl, M. Schwanninger and P. Lechner, Waste Manage., 28, 1699 (2008), https://doi.org/10.1016/j.wasman.2007.08.003

35 C. Giovannini, D. Montecchio, P. Gioacchini, O. Francioso and C. Ciavatta, Dyn. Soil Dyn. Plant, 3, 86 (2009),

http://www.globalsciencebooks.info/Online/GSBOnlin e/images/0906/DSDP_3(SI1)/DSDP_3(SI1)86-92o.pdf 36 AOAC (Association of Official Analytical Chemists), $15^{\text {th }}$ ed., Association of Official Analytical Chemists, Washington, DC, USA, 1990, https://law.resource.org/pub/us/cfr/ibr/002/aoac.metho ds.1.1990.pdf

37 "A Manual of Laboratory Techniques", National Institute of Nutrition, Hyderabad, Indian Council of Medical Research, 1976, pp. 1-5.

38 M. Saleh-e-In, S. Yeasmin, B. K. Paul, M. Ahsan, Md. Z. Rahman et al., Sugar Tech., 14, 109 (2012), https://doi.org/10.1007/s12355-012-0139-z

39 P. B. Gangavati, M. J. Safi, A. Singh, B. Prasad and I. M. Mishra, Thermochem. Acta, 428, 63 (2005), https://doi.org/10.1016/j.tca.2004.09.026

40 C. G. Mothe and I. C. Miranda, J. Therm. Anal. $\begin{array}{llll}\text { Calorim., } & 97, & 661 & \text { (2009), }\end{array}$ https://doi.org/10.1007/s10973-009-0346-3

41 Y. Hu, O. Hamed, R. Salghi, N. Abidi and S. Jodeh, Cellulose Chem. Technol., 51, 263 (2017), http://www.cellulosechemtechnol.ro/pdf/CCT34(2017)/p.263-272.pdf

42 P. Noguera, M. Abad, V. Noguera, R. Puchades and A. Maquieira, Acta Hortic., 517, 279 (2000), https://doi.org/10.17660/ActaHortic.2000.517.34

43 A. Oladayo, J. Appl. Sci. Environ. Manage., 14, 55 (2010), https://doi.org/10.4314/jasem.v14i1.56490

44 J. W. Nelly and E. G. Isacoff, "Carbonaceous Adsorbents for the Treatment of Ground and Surface Water", Marcel Dekker Inc., 1982

45 R. Sudesh, S. Kunwar and O. Priyanka, South African J. Chem. Eng., 19, 1 (2014), https://journals.co.za/content/chemeng/19/1/EJC15711 6 
46 N. Gupta, S. Tripathi and C. Balomajumder, Fuel, 90, 389

(2011),

https://doi.org/10.1016/j.fuel.2010.08.021

47 A. C. Phukan and R. K. Boruah, Sep. Purif. Technol., 17, 189 (1999), https://www.sciencedirect.com/journal/separationandp urificationtechnology/vol/17/issue/3

48 P. G. Afshar, M. Honarvar, M. Gharachorloo, P. Eshratabadi and B. Bazyar, Adv. Environ. Biol., 8, 1053

(2014),

https://www.researchgate.net/publication/275347674

49 J. Paramanandham and P. Ronald Ross, Int. J. Res. Pure Appl. Chem., 2, 1 (2015), https://www.researchgate.net/publication/302904251

50 R. Subha and C. Namasivayam, Ind. J. Chem. Tech., 16, 471 (2009), https://doi.org/10.1080/10889860903455360

51 G. Rojith and I. S. B. Singh, Int. J. Environ. Bioenerg., $\quad 3, \quad 46 \quad$ (2012), www.modernscientificpress.com/Journals/IJEE.aspx

52 Z. Laili, M. S. Yasir, M. Omar, M. Z. Ibrahim and E. Philip, Sains Malaysiana, 39, 90 (2010)

53 S. S. Nielsen, "Food Analysis", $4^{\text {th }}$ ed., Springer, 2010, Chapter 14 and 23, https://www.springer.com/gp

54 E. Lankmayr, J. Mocak and K. Serdt, J. Biochem. Biophys. Methods, 61, $95 \quad$ (2004), https://doi.org/10.1016/j.jbbm.2004.04.007

55 M. B. Inarkar and S. S. Lele, International Scholarly Research Network, ISRN Agronomy, 2012, pp. 1-6, https://doi.org/ 10.5402/2012/340158

56 Y. Athukorala, G. Mazza and B. D. Oomah, Eur. J. Lipid Sci. Tech., 111, $705 \quad$ (2009), https://doi.org/10.1002/ejlt.200800269

57 Y. S. Lin and C. W. Dence, "Methods in Lignin Chemistry", Springer, Berlin, 1992, pp. 222-226, https://www.springer.com/gp

58 T. R. Satyakeerthy, Ph.D. Thesis, School of Environmental Studies, Cochin University of Science and Technology, Cochin, Kerala, 1992

59 S. K. Saw, G. Sarkhel and A. Choudhury, Appl. Surf. Sci., 257, $3763 \quad$ (2011), https://doi.org/10.1016/j.apsusc.2010.11.136
60 M. Jablonsky, M. Botkova, J. Kocis and J. Sima, Cellulose Chem. Technol., 49, 267 (2015), http://www.cellulosechemtechnol.ro/pdf/CCT34(2015)/p.267-274.pdf

61 L. M. Kline, D. G. Hayes, A. R. Womac and N.

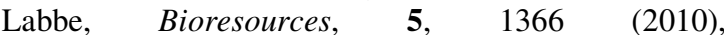
https://doi.org/10.15376/biores.5.3.1366-1383

${ }^{62}$ T. S. Anirudhan, P. Senan and M. R. Unnithan, Sep. Purif. Technol., 52, 512 (2007)

63 M. M. Abou-Mesalam, Colloid. Surface A Physicochem. Eng. Asp., 225, 85 (2003), https://doi.org/10.1016/S0927-7757(03)00191-2

64 J. L. Davila-Rodriguez, V. A. Escobar-Barrios, K. Shirai and J. R. Rangel-Mendez, J. Fluor. Chem., 130, 718

https://doi.org/10.1016/j.jfluchem.2009.05.012

(2009),

65 A. G. Moses, K. Maobe and R. M. Nyarango, Global J. Pharm., 7, $61 \quad$ (2013), https://doi.org/0.5829/idosi.gjp.2013.7.1.7226

66 W. H. Ho, K. D. Hyde, I. J. Hodgkiss and K. Yanna, Mycol. Res., 105, 1492 (2001), https://doi.org/10.1017/S095375620100507X

${ }^{67}$ E. Saberikhah, J. Mohammadi-Rovshandeh and M. Mamaghani, Cellulose Chem. Technol., 47, 410 (2013),

http://www.cellulosechemtechnol.ro/pdf/CCT56(2013)/p.409-418.pdf

68 M. Amar, R. Khiari, B. Berrima, M.N. Belgacem and E. Elalout, Cellulose Chem. Technol., 48, 255 (2014),

http://www.cellulosechemtechnol.ro/pdf/CCT34(2014)/p.255-263.pdf

${ }^{69}$ C. G. Boeriu, D. Bravo, R. J. A. Goselink and J. E. G. van Dam, Ind. Crop. Prod., 20, 205 (2004), https://doi.org/10.1016/j.indcrop.2004.04.022

70 U. J. Etim, S. A. Umoren and U. M. Eduok, J. Saudi Chem. Soc., 20, S67 (2016), https://doi.org/10.1016/j.jscs.2012.09.014 